\section{The impact of $\mathrm{CEO}$ characteristics on organizational culture and on the silo effect}

\author{
Cristina Mouta ${ }^{1}$ \\ Raquel Meneses $^{2}$
}

\section{Abstract}

Purpose - The purpose of the study is to understand the impact of psychological and observable $\mathrm{CEO}$ characteristics on organizational culture and silos.

Design/methodology/approach - A questionnaire was built using information collected during the literature review stage and emailed to the firm decision-makers. Using survey data from 185 small-to-medium-sized firms from two sectors accommodation and food, beverage, and tobacco - a structural equation model was applied to determine if the theoretical model could be confirmed or not, and the partial least squares technique was used to check if certain relationships exist.

Findings - General support was found for a theoretical model in which CEO personality traits, particularly conscientiousness, openness to experience, and extraversion, influence both organizational culture and silos, and observable variables such as age and management tenure influence the ability of the firm to develop internal coordination competences, thus inhibiting the appearance of silos.

Originality/value - The main contribution to the knowledge lies in the combination of different theoretical frameworks and the empirical approach used to test the importance of CEO characteristics in organizations and in their ability to develop cooperation networks.

Keywords - CEO, Big Five Framework, Competing Values Framework, Organizational Culture, Silos.

1. Polytechnic of Porto, Business Administration, Vila do Conde, Portugal

2. University of Porto, Management, Porto, Portugal

How to cite:

Mouta, C., Meneses, R. (2021). The Impact of CEO Characteristics on Organizational Culture and on the Silo Effect. Revista Brasileira de Gestâo de Negócios, 23(2), firstpage-lastpage.
Received on:

09/16/2019

Approved on:

$10 / 05 / 2020$

Responsible Editor:

Prof. Dr. Gina Santos

\section{Evaluation process:}

Double Blind Review

\section{Reviewers:}

Nuno Fernandes Crespo; Beatriz Casais

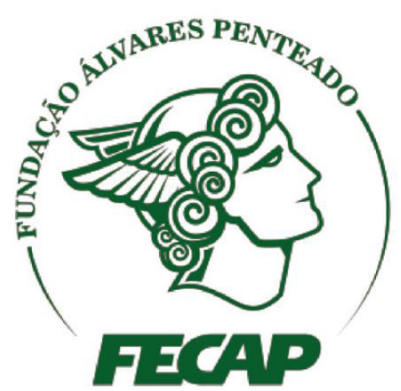

Revista Brasileira de Gestáo de Negócios

https://doi.org/10.7819/rbgn.v23i2.4100 


\section{Introduction}

The business world is now regarded as a web of relationships (Johanson \& Vahlne, 2009), and if firms want to achieve their goals, they need to develop collaboration networks with other organizations (Alexander, 2014). Collaboration among organizations is critical and enhances synergies between them, and non-collaboration leads to potential losses (Hotaran, 2009).

The choices and actions of each firm depend on other firms' choices and actions, which are a result of the influence of senior executives (Carpenter, Geletkanycz, \& Sanders, 2004). In fact, the Upper Echelons Theory highlights the influence of top management teams on firms' outcomes. Hambrick and Mason (1984) and Zacharias, Six, Schiereck, and Stock (2015) found that a firm's strategic actions are influenced by the CEO.

There remains a lack of research on the psychological characteristics of top executives (Barsade, Ward, Turner, \& Sonnenfeld, 2000) and on the relationships between CEO characteristics and firm performance (Araujo-Cabrera, Suarez-Acosta, \& Aguiar-Quintana, 2017).

Therefore, the purpose of the present study is to find out how CEOs' personality traits such as extraversion, conscientiousness, openness to experience, agreeableness, and emotional stability - the five dimensions of personality presented by the Big Five Framework (Barrick \& Mount, 1991) - and observable CEO variables such as age, formal education, management experience, and managerial tenure influence organizational culture (Schein, 1984) and the silo effect (Stone, 2004b). The study used a sample of 185 firms from two sectors - accommodation and food, beverage, and tobacco industries - in the structural equation model. The "silo effect" is an expression used to describe "a lack of communication and common goals between departments in an organization" (Hotaran, 2009, p. 216).

This paper begins with a brief review of the literature on CEO psychological characteristics, observable CEO variables, organizational culture, and internal network cooperation (the lack of a silo effect). Then, there is a presentation of the theoretical framework, followed by the research hypotheses, methodology, and discussion of the results. Lastly, the findings are presented, along with some of the limitations of the work and possible directions for future research.

\section{Literature Review}

Since the objective of this study is to try to understand the influence of CEO characteristics on organizational culture and on the development of intracollaboration networks, a review is carried out of the main theories concerning organizational culture and the silo effect, as well as psychological and observable CEO characteristics.

\section{I The Chief Executive Officer (CEO)}

The $\mathrm{CEO}$ is arguably the most powerful member of the top management team (Crossland \& Hambrick, 2007), and Hambrick and Mason (1984) found in their research that there is a connection between an organization's performance and the top managers who manage it - this is part of the Upper Echelons Theory. In fact, CEO characteristics are assumed to impact strategic decisionmaking processes (Papadakis \& Barwise, 2002).

The CEO's personality can influence the entire decision process dynamic, and how this impacts the firm's performance, namely in terms of sales growth and returns on investment and assets (Peterson, Smith, \& Martorana, 2003).

It is noted that personality characteristics influence the way CEOs process information about their capabilities, the firm, and the environment (Finkelstein, Hambrick, \& Cannella, 2009).

Further research has revealed the existence of strong links between $\mathrm{CEO}$ characteristics and the patterns of behavior and interaction among members of an organization (Giberson et al., 2009). Moreover, O’Reilly III, Caldwell, Chatman, and Doerr (2014b, p. 620) found strong evidence that the CEO's personality "may have significant effects on the culture of the company."

\section{I.I Psychological characteristics}

Lately, some management researchers have focused their attention on assessing whether differences in personality traits can influence firm performance or not, and to accomplish this they have used the Big Five dimensions of personality (Abatecola, Mandarelli, \& Poggesi, 2013; Barrick \& Mount, 1991; Gow, Kaplan, Larcker, \& Zakolyukina, 2016; Kaplan \& Sorensen, 2017; Nadkarni \& Herrmann, 2010).

The Big Five Framework is a personality model with five factors or traits, suggesting that most individual characteristics can be grouped into five personality 
dimensions: extraversion, emotional stability, agreeableness, conscientiousness, and openness to experience (Digman, 1990). In general, researchers agree that the Big Five dimensions are a good instrument for classifying personality characteristics (Digman, 1990). The five traits and their impact on human personality were proficiently explained by Costa and McCrae (1992), who defended the idea that most of the variables used to assess personality in academic research could be aggregated in one or more of the factors of the Big Five Framework.

Nadkarni and Herrmann (2010) used the framework to study whether CEO personality traits enhance or inhibit strategic flexibility. Abatecola et al. (2013) used the Big Five Framework to verify if there were any associations between CEO emotional stability, extraversion, and conscientiousness, and the firm's performance and strategic pro-activity. O’Reilly III, Doerr, Caldwell, and Chatman (2014a) used the framework to assess if CEO personality influences the firm's culture and if culture impacts organizational outcomes. Gow et al. (2016) used it to analyze whether differences in personality characteristics can be related to managers' investment and financing decision-making and firm performance. Kaplan and Sorensen (2017) studied if CEOs were any different from other managers, using the Big Five Framework.

\section{I.I.I Big Five personality dimensions}

Using this framework, it is possible to assess the degree to which the CEO can be described as having each of the factors of the Big Five dimensions (Gow et al., 2016). An organization with a CEO scoring highly in the openness to experience factor will probably present an organizational culture with characteristics closer to an "entrepreneurial culture," but if the CEO has a high score in the second trait - agreeableness - the organizational culture will show features of a "team culture."

A high score for the first dimension - extraversion - suggests the individual is sociable, talkative, assertive, active, full of energy, and enthusiastic; a low score suggests the individual is cautious, introverted, and quiet. Research has revealed that an extroverted CEO shows more flexibility and is more likely to start a strategic change (Nadkarni \& Herrmann, 2010); however, an extroverted CEO may play a dominant role within the team, and so the benefits may be dependent on team obedience or submissiveness (Gow et al., 2016). This factor can facilitate the creation of internal and external cooperation networks by recognizing the importance of working as a team, and by making it easier to connect with others. On the other hand, it can lead to a culture that is too team-based, with a great deal of competition among teams, leading to the appearance of silos. Agreeableness - the second trait - reveals a person's tendency to easily agree with others, to be kind, flexible, cooperative, good-natured, and tolerant. A person with a high score is seen as altruistic and trustworthy, and as preferring cooperation over competition. TMTs with CEOs scoring highly in agreeableness are more likely to be cohesive and decentralized, as the CEO may encourage the team to share information, achieve common goals, and seek consensus (Peterson et al., 2003). Such CEOs are more likely to create a more team-oriented organizational culture, promoting both internal and external cooperation.

A high score for the third factor - conscientiousness - suggests that the individual is reliable, responsible, careful, and organized. This dimension is a good indicator of a person's job performance. Individuals with a high score tend to be more task-oriented than relationshiporiented. Teams led by this kind of individual are also more task-focused, working according to high ethical and legal standards (Peterson et al., 2003). Nadkarni and Herrmann (2010) found a positive relationship between this factor and book-to-market, which is consistent with the findings of Gow et al. (2016) that this trait is negatively related to the firm's growth. Some research has revealed that CEOs with a high score in conscientiousness feel less attracted to innovative cultures, risk-taking, and innovation (O'Reilly III et al., 2014b), thus leading to poor firm growth (Gow et al., 2016). Such individuals may increase internal cooperation, but could be too rigid to increase external cooperation networks.

Emotional stability (or neuroticism) is the fourth dimension considered, and a person with a low score tends to react impulsively and anxiously. If they present a high score, the individual tends to be calm, less anxious, emotionally stable, and shows some self-confidence. Emotionally stable CEOs are more willing to take risks, to face new situations, and feel more attracted to innovative firms (Gow et al., 2016), and they are less likely to cause conflicts among team members (Peterson et al., 2003). These CEOs are more likely to promote both internal and external cooperation networks, if they show a selfconfident profile.

Lastly, the openness to experience factor reveals how much a person is open to new ideas and experiences. An individual with a low score is narrow-minded, while one with a high score is creative, imaginative, cultured, original, broad-minded, and reflective. Research has 
shown a positive relationship between this trait and $R \& D$ intensity, and a negative association with net leverage, which is supported by the idea that CEOs with a high score in openness are more likely to pursue new ideas, processes, and experiences (Gow et al., 2016). Therefore, the likelihood of establishing and managing internal and/or external networks as a means for gaining access to resources, new markets, innovation, knowledge, and technology increases significantly. For Nadkarni and Herrmann (2010), there is a positive association between this factor and strategic flexibility, which favorably impacts firm performance. Being more open to and tolerant of others also causes an impact on culture.

Hypothesis 1 - CEO psychological characteristics impact organizational culture.

CEOs with a low score in the extraversion dimension of the Big Five Framework, and who are thus cautious, introverted, and quiet, will have more difficulty in developing their share capital, and therefore business relationships and cooperation networks. Likewise, an executive with a low score in agreeableness will be regarded as being untrustworthy and will be unable to connect with other managers, as these may be reluctant to develop any kind of personal or business relationship with that executive. This may happen because most firms prefer to negotiate with individuals with a reputation for avoiding risks, instead of relying on institutional arrangements (Granovetter, 1985).

Extroverted CEOs may play a dominant role within the team (Gow et al., 2016), as they tend to be sociable, talkative, assertive, active, and full of energy (Costa \& McCrae, 1992), and so they are more likely to positively impact organizational culture, mainly in terms of helping to create an organizational team culture.

Hypothesis 1.a. - CEOs with a high extraversion score tend to create a team culture.

Additionally, CEOs with a high agreeableness score are more likely to be cohesive and decentralized, as they may encourage the team to share information, achieve common goals, and seek consensus (Peterson et al., 2003).

If the $\mathrm{CEO}$ has a high agreeableness score, then the organizational culture will most likely be close to a "team culture", because individuals with a high agreeableness score are kind, cooperative, flexible, and tolerant (Costa $\&$ McCrae, 1992).

Hypothesis 1.b. - CEOs with a high agreeableness score tend to create a team culture.

Furthermore, individuals with a high conscientiousness score tend to be reliable, responsible, organized, and more task-oriented, and are more likely to create a rational culture. Some research has revealed that CEOs with a high conscientiousness score feel less attracted to innovative cultures, risk-taking, and innovation (O’Reilly III et al., 2014b).

Hypothesis 1.c. - CEOs with a high conscientiousness score tend to create a rational culture.

Also, emotionally stable CEOs are more willing to take risks and face new situations and feel more attracted to innovative firms (Gow et al., 2016). They are less likely to cause conflicts among team members (Peterson et al., 2003), but are more likely to create an entrepreneurial culture.

Hypothesis 1.d. - CEOs with a high emotional stability score tend to create an entrepreneurial culture. An organization with a CEO that scores highly in the openness to experience factor will probably present an organizational culture with characteristics closer to those of an "entrepreneurial culture," since these CEOs are regarded as creative and open to new ideas and experiences (Gow et al., 2016).

Hypothesis 1.e. - CEOs with a high openness to experience score tend to create an entrepreneurial culture. Hypothesis 2 - Some CEOs' psychological characteristics impact organizational silos.

Respondents to a survey on internal collaboration conducted by the American Management Association pointed to manager attitude as the main cause for the existence of silos (Stone, 2004). Stone (2004) argued that the leader's personality or management style may prevent or encourage problems among departments and therefore contribute to creating the silo effect, making it more difficult for employees to establish informal relationships among themselves and with stakeholders. Therefore, a more extroverted or agreeable CEO may be more likely to prevent the existence of organizational silos.

Hypothesis 2.a. - A CEO with a high extraversion score impacts organizational silos.

Hypothesis 2.b. - A CEO with a high agreeableness score impacts organizational silos.

However, if the $\mathrm{CEO}$ communicates consistent and coordinated goals and ensures that there is a flow of information through management and among functional areas and that responsibility and work processes are clearly established while promoting inter-departmental meetings, the organization may be well prepared to avoid the silo effect (Schütz \& Bloch, 2006). In such cases employees will be encouraged to jointly develop activities and information-sharing initiatives and to work with whoever 
is needed to get the job done. A more conscientiousness CEO may be better prepared to avoid the silo effect within an organization.

Hypothesis 2.c. - A CEO with a high conscientiousness score impacts organizational silos.

\section{I.2 Observable characteristics}

The literature review of analyses of CEO characteristics revealed that most of the research has focused on observable rather than on psychological characteristics, such as age, formal education, functional background, and management tenure, because these are observable and measurable (Wang, Holmes, Oh, \& Zhu, 2016).

\section{I.2.I Age}

Considering the CEO's age as being the length of time they have lived until the data collection, older CEOs means people with more life experience and history, which certainly influences CEO behavior. For example, according to Hambrick and Mason (1984), younger CEOs tend to take riskier decisions than older ones, which will be reflected in their strategic actions, and, in due time, in the firm's performance.

\section{I.2.2 Formal education}

The CEO's formal education is defined as their educational level. Executives' educational background reveals their knowledge, values, and skills, which may impact organizational performance, if they are better prepared to interpret the environment (Hambrick \& Mason, 1984).

Moreover, the CEO's formal education was found to have a positive effect on the firm's strategic actions, and, therefore, on the firm's future performance (Wang et al., 2016a).

\section{I.2.3 Management experience}

This characteristic relates to the CEO's experience in major roles, either in a different industry or organization, or with strategic actions. Prior career experience in any given area of expertise, or role, would better prepare a CEO to develop their firm's strategic actions (Wang et al., 2016a). Research has revealed that a wider range of experience leads to a better and more thorough evaluation of alternatives, since the CEO has access to a larger pool of perspectives and skills (Simons, Pelled, \& Smith, 1999).

\section{I.2.4 Managerial tenure}

CEO tenure is the length of time they have served as a CEO. Luo, Kanuri, and Andrews (2014) analyzed how CEO tenure impacts firm performance and found that it is positively related to the strength of the firm-employee relationship and negatively related to the strength of the firm-customer relationship, as well as having an effect on firm performance. Further research has revealed that CEO tenure is negatively associated with the firm's strategic actions, and positively related to the firm's future performance (Wang et al., 2016).

Hypothesis 3 - CEO observable characteristics impact organizational culture and silos.

Observable characteristics such as age, formal education, managerial tenure, and management diversity are positively associated with the firm's strategic actions (Wang et al., 2016a) and may establish a link with the organization's internal factors such as risk-taking, communication, or social integration (Eisenhardt \& Schoonhoven, 1996).

Also, Karami, Analoui, and Korak Kakabadse (2006) found that young senior managers tend to take riskier decisions and adopt more innovative strategies than older managers. Moreover, a more risk-taking CEO will encourage the creation of more flexible organizational cultures (Kalliath, Bluedorn, \& Strube, 1999).

Hypothesis 3.a. - Younger CEOs tend to create entrepreneurial cultures.

CEOs with a high educational level tend to adopt organizational cultures that favor creativity and innovation and that respond well to environmental changes (Blundell, Dearden, Meghir, \& Sianesi, 1999).

Hypothesis 3.b. - CEOs with high educational levels tend to create entrepreneurial cultures.

An organization is a result of people's behaviors, as people outline the way an organization looks, feels, and behaves. Therefore, people's characteristics "are the fundamental determinants of organizational behavior" (Schneider, 1987, p. 437). If people outline the way an organization behaves, then individuals' characteristics are determinants of organizational performance (Schneider, 1987).

CEO characteristics not only impact organizational performance, but some CEO characteristics might be expected to have an influence on organizational culture, as it can be seen on the Theoretical Framework (Fig. 1). 


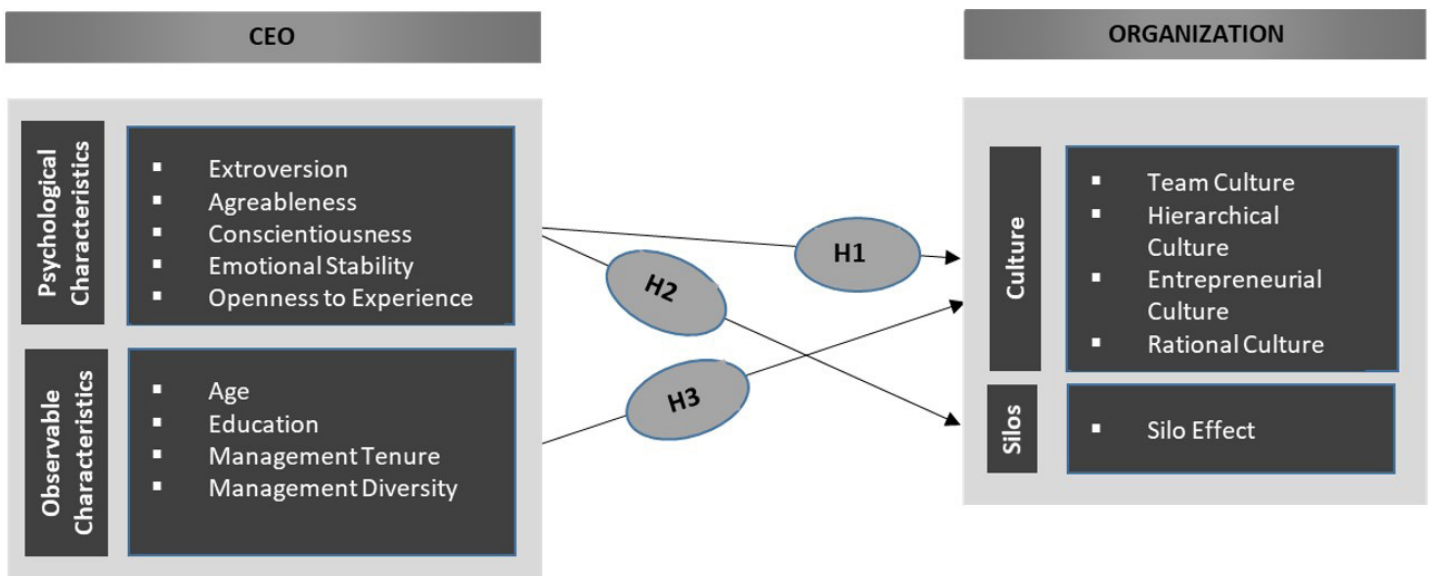

Figure 1. Theoretical Framework

\subsection{The organization}

Organizations are linked by networks of personal relationships (Granovetter, 1985) and are regarded as open systems, as they depend on continuous exchanges with the environment (Katz \& Kahn, 1966). If they want to survive, they must adapt to the environment (Hambrick, 1982). Thus, firms with CEOs with a given set of characteristics and greater share capital will be better positioned to establish business relationships and networks.

\subsection{Silo effect/ lack of internal network cooperation}

Collaboration within organizations is critical: when there is a lack of communication and common goals among an organization's departments, then it can be said there is a silo effect in the organization (Hotaran, 2009). This concept is used when functional areas work alone, with very little communication with each other (Cromity \& Stricker, 2011).

If an organization has a silo effect, it means that the employees tend to work autonomously, overlook organizational objectives, and are often reluctant to form part of multi-functional teams (Vatanpour, Khorramnia, $\&$ Forutan, 2013), meaning that there is a lack of internal network cooperation.

There is a silo mentality in an organization if the individuals only focus on working in favor of their best interests, with the aim of achieving their best performance regardless of the influence their behavior might have on others, or on the organization (Hotaran, 2009).

Silos only exist in the minds of employees. While they are present in organizations, they create barriers that influence work behavior (Cilliers \& Greyvenstein, 2012) and impact the way the firm and employees perform and the customers (Fenwick, Seville, \& Brunsdon, 2009).

\subsubsection{Organizational culture}

There are many definitions of organizational culture, and many types (Melé, 2003). Schein (1984, p. 3) defined organizational culture as:

“...a pattern of basic assumptions that a given group has invented, discovered, or developed in learning to cope with its problems of external adaptation and internal integration, and that have worked well enough to be considered valid, and, therefore, to be taught to new members as the correct way to perceive, think, and feel in relation to those problems."

Therefore, culture is presented as a set of assumptions one makes about a group one belongs to, and those assumptions can be grouped into three levels: artifacts, espoused beliefs and values, and basic underlying assumptions. These differentiate the levels at which organizational culture is manifested.

Organizations are social, so it is important to study how organizational culture affects firms (Hogan \& Coote, 2014). Reinforcing this idea, Groysberg, Lee, Price, and Cheng (2018) found that the closer employees feel to culture elements, the more motivated and engaged they are. This also influenced the way employees relate to each other, and how they look after new members (Helfrich et al., 2007).

Although the Competing Values Framework (CVF) was originally developed to assess the organizational 
value system and organizational effectiveness, it quickly became one of the most widely used instruments in the area of organizational culture research. The tool was first developed by Quinn and Rohrbaugh (1983) and later refined by Cameron (2009).

The CVF considers that most organizations can feature two dimensions of competing values (Kalliath et al., 1999). The first one, flexibility/decentralization vs. control/ centralization, reflects the importance given to control, predictability, and stability or to flexibility and adaptability within the organization. The second dimension involves the internal vs. external focus, revealing how concerned the organization is with what happens within its limits, or in its environment and in the relationships with its stakeholders. If the organization is internally focused, it values the functions and the development of human resources within the organization. If it is externally focused, then it gives more attention to its development within the wider environment (Grabowski, Neher, Crim, \& Mathiassen, 2015).

Each axis represents a dimension. Crossclassifying them results in four quadrants, each one associated with a culture type (see Figure 2). Nevertheless, an organization can rarely be classified in one single quadrant; in fact, it will show values from different quadrants, with more emphasis on one or two (Buschgens, Bausch, \& Balkin, 2013).
In any case, whatever the culture type an organization presents, the main thing is to understand the impact of organizational culture on how organizations work (Schein, 1996). Besides leadership, organizational culture plays an important role in knowledge transfer, and this requires individuals' willingness to work with others and share knowledge to their benefit, as well as breaking down hierarchies within the organization (Goh, 2002).

\section{Methodological Procedures}

This research follows a positivist line of thought since it uses a self-completed questionnaire to collect the data, and quantifiable methods and statistical techniques to be able to obtain generalizations, and thus valid knowledge.

\section{I Data collection}

CEOs of firms belonging to two different sectors (accommodation activities and the food, beverage, and tobacco industry) were invited to answer a questionnaire that takes the literature review into consideration, with the purpose of collecting data related to each construct of the empirical model and observing how those constructs relate to each other. The two sectors were chosen due to their different stages of growth, since the literature argues that industry has a moderating effect. Hence, we decided to study two sectors: accommodation activities,

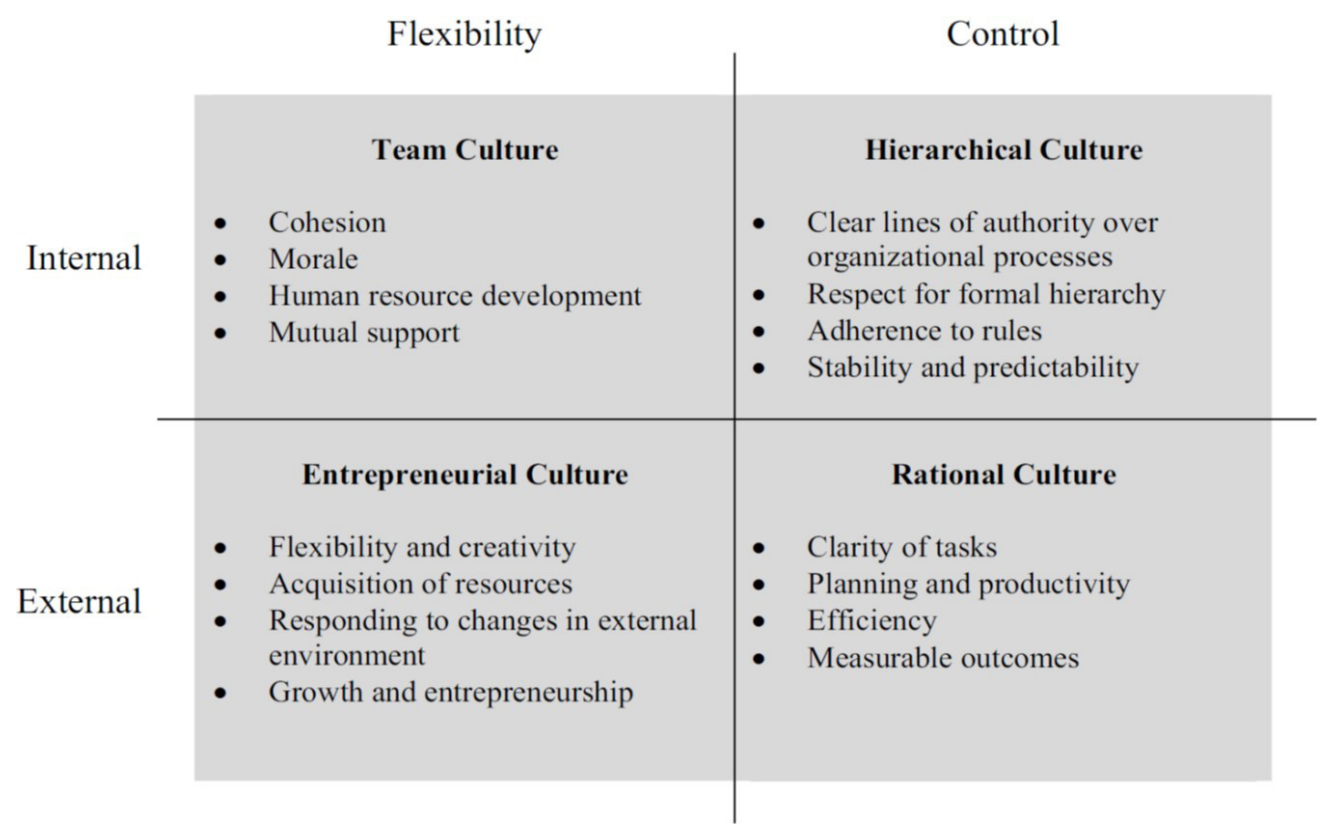

Figure 2. The Competing Values Framework of Organizational Effectiveness, adapted from "A Test of Value Congruence Effects" from T.J. Kalliath, A. C. Bluedorn, \& M. J. Strube, 1999, p. 4. 
which belong to the more dynamic services sector; and the food, beverage, and tobacco industry, which shows more sustained growth.

After validating the questionnaire, an email was sent with an introductory message and a link to the webpage with the online questionnaire, to 5,556 active firms from the accommodation activities sector and from the food, beverage, and tobacco industry. The questionnaire was available online for two months, and the contacts were sent a reminder message on a weekly basis. At the end of this period there were 185 completed questionnaires. If a questionnaire was returned unfinished, then it was excluded from the study.

\subsection{The questionnaire and the scales}

The questionnaire contained two groups of questions: one related to the individual and the $\mathrm{CEO}$ characteristics, and the second more focused on the organization, namely on culture and the silo effect (see Appendix 1 for the scales).

The first question in the questionnaire was a filter question. If the person who opened the questionnaire was not the $\mathrm{CEO}$ or the General Manager/Managing Director/Partner, then the questionnaire ended, and the person was thanked for their time. If they were the CEO or the person in charge of the decision-making process, then the questionnaire proceeded.

The Big Five Framework was used to assess the effects of CEO personality on the organization (Costa $\&$ McCrae, 2004). The CEO's observable variables were chosen after considering the existing literature on the subject (Finkelstein \& Hambrick, 1990; Hambrick, 2007; Hambrick \& Mason, 1984; Hambrick \& Quigley, 2014). The type of organizational culture was assessed using the Competing Values Framework (Quinn \& Rohrbaugh, 1983). The possible existence of a silo effect was assessed using nine statements which were formulated by the researcher, but were inspired by the existing literature (Cilliers \& Greyvenstein, 2012; Stone, 2004a). These were called "silos." The last seven statements were adapted from the scale used by Lee, Vargo, and Seville (2013) to measure and compare organizations' resilience, as the silo effect can influence organizational resilience (Lee et al., 2013). Of these seven statements, the first four were called "lack of silo mentality," since they focused on finding out if there were any intra or inter organizational barriers, if there was a team spirit, and whether or not people were encouraged to play different roles within the organization. They were therefore related to the existence or inexistence of a silo mentality. The remaining three were denominated "communications and relationships," as in the original work of Lee et al. (2013). These were related to the way the firms are viewed within the industry, how the firms establish and develop relationships with their stakeholders (customers and providers), and how employees work to accomplish their tasks regardless of any boundaries that might exist between functional areas or organizations. Therefore, this "communications and relationships" construct assesses the firm's informal relationships, not only internally but also externally, and evaluates the health of relationships with the firm's stakeholders. So, the existence of an organizational silo effect is assessed by three constructs: "silos," "lack of silo mentality," and "communications and relationships." Before being included in the questionnaire, all these scales were translated from the English language into Portuguese. A back translation was also carried out to ensure the quality of the translation. During the preparation of the questionnaire, there was constant concern about using scales which had already been used, tested, and validated by previous research, although in different contexts. The questionnaire was tested in a small sample of firms to test the sequence and coherence of the questions and to validate it.

\subsection{Data analysis}

The CEOs surveyed were, on average, 49 years old, $70 \%$ male, and at least $45 \%$ had a degree, but only $41.6 \%$ were educated in the management field.

Of all the firms present in the sample, $73.5 \%$ had a turnover of less than or equal to two million euros. Nearly $46 \%$ of the firms had less than 10 employees and $40 \%$ had more than 10 but less than 50 employees.

The structural equation model (SEM) used consists of a collection of statistical techniques that allow for the analysis of a number of associations between one or more continuous or discrete independent variables, and one or more continuous or discrete dependent variables (Ullman \& Bentler, 2012). This approach allowed for it to be determined whether or not the previously obtained theoretical model could be confirmed, and whether or not the linear relationships among the variables of the model were real. One major advantage of this confirmatory method lies in the possibility of allowing the researcher to 
assess and change the theoretical model, as necessary, thus offering "great potential for furthering theory development" (Anderson \& Gerbing, 1988, p. 411).

First, the model was designed and consisted of various relationships among the constructs and their indicators. Some variables such as age, education, management experience, and management tenure were outlined as observable variables, while the others were considered as latent variables, since they can only be indirectly measured by their indicators, which are, in turn, their observable manifestations. The ability of these indicators to reflect their corresponding construct is determined by the size of the loadings (Chin, 1998).

The advantages of using SEM include the possibility of using both types of variables (latent and manifest). SEM also provides no default model and places few limitations on what types of relationships can be found among the variables. It only requires the researchers to support the hypothesis with theory or research. The categories were edited using scales already tested by other researchers, but when this was not possible, scales were developed with the support of the available theory, as in the case of the "silo effect" construct.

The SEM's parameters were estimated following two different techniques: covariance structure modeling (CSM) and partial least squares (PLS). The first category focuses on determining variable covariances, while PLS concentrates on error minimization. Both use different estimation algorithms and differ in terms of the type of models that can be estimated, the type of indicators allowed, and the statistical tests. CMS estimates the covariances of all observed variables, while PLS follows an iterative sequence of generalized least squares, analyzing each latent variable one at a time. Using multiple linear regressions for the latent variable estimates minimizes the residual variance of all dependent variables (Marôco, 2010).

The CSM approach aims to minimize the difference between the sample covariances and those predicted by the theoretical model. Thus, the parameter estimation process tries to reproduce a covariance matrix of the observed measures (Chin, 1998).

A PLS model presents a structural part, evidencing the relationships among the latent variables, a measurement element, which shows how the latent variables and their indicators are related, and the weight relationships, which are used to estimate case values for the latent variables (Chin, 1998).
In this case, we decided to use the PLS technique, since it allows not only for the theory to be confirmed, but also suggests whether or not certain relationships exist, and suggests propositions to be tested later on (Chin, 1998). Moreover, PLS allows for relationships between reflective and formative variables (Marôco, 2010).

The model was estimated following three steps. First, the measurement model was validated using confirmatory factor analysis, followed by exploratory factor analysis, when the former did not validate the scale. Then the structural model was estimated.

\section{Presentation of Results}

Initially, a confirmatory factor analysis was performed to check if the scales used in other settings were valid in this study context. In a confirmatory factor analysis, the aim of the researcher is to assess the weight of each scale item and how well the scale measures the construct (Hair, Black, Babin, \& Anderson, 2010); this is called construct reliability.

This procedure was only carried out for the reflexive scales, since it is not necessary to study the validity and reliability of formative constructs (Wong, 2013).

The suitability of the scales was verified using the PLS algorithm, which revealed some problems with

Table 1

\section{Construct Reliability and Validity Table}

\begin{tabular}{lccc}
\hline & $\begin{array}{c}\text { Cronbach's } \\
\text { Alpha }\end{array}$ & $\begin{array}{c}\text { Composite } \\
\text { Reliability }\end{array}$ & $\begin{array}{c}\text { Average } \\
\text { Variance } \\
\text { Extracted } \\
\text { (AVE) }\end{array}$ \\
\hline $\begin{array}{l}\text { Agreeableness } \\
\text { Communications } \\
\text { and Relationships } \\
\text { Conscientiousness }\end{array}$ & -0.104 & 0.096 & 0.439 \\
$\begin{array}{l}\text { Education } \\
\text { Emotional }\end{array}$ & 0.174 & 0.867 & 0.686 \\
$\begin{array}{l}\text { Stability } \\
\text { Entrepreneurial }\end{array}$ & -0.306 & 0.601 & 0.517 \\
$\begin{array}{l}\text { Culture } \\
\text { Extraversion }\end{array}$ & 0.830 & 0.835 & 0.507 \\
$\begin{array}{l}\text { Hierarchical } \\
\text { Culture }\end{array}$ & 0.115 & 0.693 & 0.631 \\
$\begin{array}{l}\text { Openness to } \\
\text { Experience }\end{array}$ & 0.772 & 0.868 & 0.651 \\
$\begin{array}{l}\text { Rational Culture } \\
\text { Silo Mentality }\end{array}$ & 0.816 & 0.890 & 0.731 \\
$\begin{array}{l}\text { Silos } \\
\text { Team Culture }\end{array}$ & 0.777 & 0.858 & 0.604 \\
\hline & 0.766 & 0.832 & 0.459 \\
& 0.723 & 0.844 & 0.643 \\
\hline
\end{tabular}


constructs such as agreeableness, conscientiousness, education, emotional stability, extraversion, and silos, as shown in Table 1. These presented a very low Cronbach's alpha value, which is a reliability measure ranging from 0 to 1 , where a value of 0.60 is considered the lowest limit of acceptability (Hair et al., 2010).

Besides having a low Cronbach's alpha value, the aforementioned constructs also presented composite reliability values lower than 0.7 , the recommended minimum acceptable value (Maroco \& Garcia-Marques, 2006), showing little internal consistency of the variables.

Although the silos construct presents a Cronbach's alpha of 0.766 , the AVE value is 0.459 , which is below 0.5 , the minimum acceptable value (Chin, 1998), so little variance is captured by the latent variable of its indicators.

Besides the problems mentioned, the agreeableness and emotional stability constructs also showed an AVE below the minimum acceptable value (0.5) .

As the scales used to measure the agreeableness, conscientiousness, emotional stability, extraversion, and silos constructs presented some problems, we decided to conduct an exploratory factor analysis of these constructs.

After determining the correlation matrix of the 12 variable indicators, the Kaiser-Meyer-Olkin criteria were used to assess whether the factor analysis was adequate or not; in this case, it presents a value of 0.6 (Table 2), which is acceptable. So, it can be said that the factor analysis model adequately fits the sample. Moreover, the significance of the Bartlett sphericity test is zero, showing the validity and suitability of the responses collected throughout the study.

After determining the number of components to be kept and checking the internal consistency among the items of the scale, it can be stated that the scales used in the model to assess the CEO psychological variables turned out to be the Big Four instead of Big Five, since only the scales used to measure extraversion, openness to experience, conscientiousness, and emotional stability/neuroticism had their reliability confirmed. The agreeableness dimension was, therefore, excluded from the model (Table 3).

The scales measuring the lack of silo mentality and communications and relationships constructs were validated by the confirmatory factor analysis. However, the silos scale was not validated. Therefore, an exploratory factor analysis was carried out and the correlation matrix and the Kaiser-Meyer-Olkin criteria were used to assess if the factor analysis was adequate or not.
The factor analysis model proved to be adequate according to the results for both the KMO and Bartlett sphericity test. In this case, the $\mathrm{KMO}$ was 0.694 , which was above the minimum accepted value, showing that there is a good correlation among the variables. The sphericity test for a significance level of 0.000 revealed that there is a correlation among some variables (Table 4).

Using the eigenvalues criteria, it was possible to verify that the nine initial components were reduced to three, as the first three components revealed eigenvalues greater than 1 . The internal consistency among the items of the scale was verified using the Cronbach's alpha value, the average variance explained, and the composite reliability.

Component 1 was called "sharing," since it includes questions related to promoting information sharing among departments, the existence of joint outof-office activities, and whether responsibilities and tasks are adequately outlined.

Table 2

\section{KMO and Bartlett Test}

\begin{tabular}{lcc}
\hline \multicolumn{2}{c}{ Kaiser-Meyer-Olkin Measure of Sampling } & $\mathbf{0 . 6 0 0}$ \\
\hline \multicolumn{2}{c}{ Adequacy } & \\
\hline Bartlett's Sphericity Test & Approx. Chi-Square & 585.485 \\
& df & 66 \\
& Sig. & 0.000 \\
\hline
\end{tabular}

Table 3

Summarized results of the 5 Dimensions

\begin{tabular}{ccccc}
\hline Dimension & $\begin{array}{c}\text { Cronbach's } \\
\text { Alpha }\end{array}$ & AVE & CR & \\
\hline Extraversion & 0.752 & 0.648 & 0.829 & $\checkmark$ \\
Conscientiousness & 0.665 & 0.749 & 0.856 & $\checkmark$ \\
$\quad$ Emotional & 0.598 & 0.657 & 0.783 & $\checkmark$ \\
$\quad$ Stability & & & & \\
Openness to & 0.772 & 0.686 & 0.868 & $\checkmark$ \\
$\quad$ Experience & & & & \\
Agreeableness & & & & $\times$ \\
\hline
\end{tabular}

Table 4

Silos KMO \& Bartlett Test

\begin{tabular}{ccc}
\hline \multicolumn{2}{c}{$\begin{array}{c}\text { Kaiser-Meyer-Olkin Measure of } \\
\text { Sampling Adequacy }\end{array}$} & $\mathbf{0 . 6 9 4}$ \\
\hline Bartlett's Sphericity & Aprox. Chi-Square & 542.292 \\
Test & df & 36 \\
& Sig. & 0.000 \\
\hline
\end{tabular}


Component 2 was called "rewards," since this component included questions related to the existence of departmental and/or organizational financial results.

Component 3 was called "independence," since it included indicators related to department autonomy, interdependent sections, and the existence of subcultures in each organizational department.

In order to analyze these three components, the orthogonal rotation was used and the loadings of the variables for each factor were obtained, as shown in Table 5.

Therefore, in summary, it can be stated that the Silos construct was measured with the sharing and rewards scales validated by this exploratory factor analysis, since component 3 revealed a bad scale fit and demonstrated a lack of reliability, and was thus excluded from the model, as summarized in Table 6 .

\section{Discussion of Results}

The standard regression weight of effects of each variable was estimated using the partial least squares regression, calculated using bootstrapping (a non-parametric

Table 5

\section{Silos Rotated Component Matrix}

\begin{tabular}{|c|c|c|c|}
\hline \multicolumn{4}{|c|}{ Rotated Component Matrix ${ }^{a}$} \\
\hline & \multicolumn{3}{|c|}{ Component } \\
\hline & 1 & 2 & 3 \\
\hline B10.1 & 0.615 & 0.382 & \\
\hline B10.2 & 0.120 & & 0.846 \\
\hline B10.4 & 0.354 & 0.300 & 0.246 \\
\hline B10.5 & 0.906 & & 0.162 \\
\hline B10.6 & 0.894 & & 0.104 \\
\hline B10.7 & & 0.125 & 0.783 \\
\hline B10.8 & 0.115 & 0.893 & 0.141 \\
\hline B10.9 & 0.140 & 0.914 & \\
\hline B10.3Rev & -0.148 & -0.122 & -0.575 \\
\hline
\end{tabular}

Notes. Extraction method: principal component analysis. Rotation method: varimax with Kaiser normalization. ${ }^{\text {a }}$

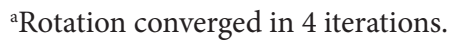

Table 6

\section{Summarized results of the components}

\begin{tabular}{ccccc}
\hline Dimension & $\begin{array}{c}\text { Cronbach's } \\
\text { Alpha }\end{array}$ & AVE & CR & \\
\hline Sharing & 0.708 & 0.573 & 0.838 & $\checkmark$ \\
Rewards & 0.858 & 0.874 & 0.933 & $\checkmark$ \\
Independence & -0.073 & 0.568 & 511 & $\times$ \\
\hline
\end{tabular}

technique). Moreover, the significance of the relationships was statistically estimated for a $95 \%$ confidence level.

Considering $\mathrm{p}$ values $<0.05$, Table 7 shows the model's statistically significant relationships and, using those relationships, a new model was redesigned (Figure 3) to have a better understanding of some of the relationships.

\section{Table 7}

\section{Statistically significant relationships for $\mathbf{p}$ value $<0.05$}

\begin{tabular}{|c|c|c|}
\hline Relationships & P Values $<0.05$ & $\begin{array}{c}\text { Standard } \\
\text { Regression } \\
\text { Weights }\end{array}$ \\
\hline $\begin{array}{l}\text { Age } \rightarrow \\
\text { Communications } \\
\text { and Relationships }\end{array}$ & 0.027 & 0.019 \\
\hline $\begin{array}{l}\text { Conscientiousness } \\
->\text { Rational Culture }\end{array}$ & 0.000 & 0.356 \\
\hline $\begin{array}{l}\text { Entrepreneurial } \\
\text { Culture -> Rewards }\end{array}$ & 0.011 & 0.370 \\
\hline $\begin{array}{l}\text { Entrepreneurial } \\
\text { Culture -> Sharing }\end{array}$ & 0.001 & 0.379 \\
\hline $\begin{array}{l}\text { Extraversion -> } \\
\text { Communications } \\
\text { and Relationships }\end{array}$ & 0.019 & 0.196 \\
\hline $\begin{array}{l}\text { Extraversion } \\
->\text { Lack of Silo } \\
\text { Mentality }\end{array}$ & 0.021 & 0.195 \\
\hline $\begin{array}{l}\text { Extraversion -> } \\
\text { Team Culture }\end{array}$ & 0.000 & 0.343 \\
\hline $\begin{array}{l}\text { Management } \\
\text { Tenure -> } \\
\text { Communications } \\
\text { and Relationships }\end{array}$ & 0.019 & -0.213 \\
\hline $\begin{array}{l}\text { Openness to } \\
\text { Experience -> } \\
\text { Entrepreneurial } \\
\text { Culture }\end{array}$ & 0.000 & 0.426 \\
\hline $\begin{array}{l}\text { Openness to } \\
\text { Experience -> } \\
\text { Sharing }\end{array}$ & 0.002 & 0.255 \\
\hline $\begin{array}{l}\text { Openness to } \\
\text { Experience -> Lack } \\
\text { of Silo Mentality }\end{array}$ & 0.016 & 0.195 \\
\hline $\begin{array}{l}\text { Rational Culture -> } \\
\text { Sharing }\end{array}$ & 0.003 & 0.336 \\
\hline $\begin{array}{l}\text { Rational Culture } \\
->\text { Lack of Silo } \\
\text { Mentality }\end{array}$ & 0.042 & 0.225 \\
\hline $\begin{array}{l}\text { Team Culture -> } \\
\text { Communications } \\
\text { and Relationships }\end{array}$ & 0.007 & 0.369 \\
\hline $\begin{array}{l}\text { Team Culture } \\
\text {-> Lack of Silo } \\
\text { Mentality }\end{array}$ & 0.035 & 0.284 \\
\hline
\end{tabular}


One thing that becomes apparent is that CEO psychological characteristics, namely conscientiousness, extraversion, and openness to experience, impact organizational culture and silos (lack of internal network cooperation), which includes communications and relationships (the construct that measures the firm's informal relationships), silo mentality, sharing, and rewards. CEO observable characteristics, namely age and management tenure, only influence the organization's ability to create and develop informal networks, reflected in the way employees relate to each other to accomplish their work, regardless of any departmental or firm boundaries that might exist, or how the firm is seen within the industry (communications and relationships).

After analyzing the data from Table 7 and the relationships represented in Figure 3, it can be concluded that hypotheses 1 and 2 were partially confirmed by the empirical research, as emotional stability was left out of the analysis. However, it was found that $\mathrm{CEO}$ conscientiousness, extraversion, and openness to experience not only influence organizational culture, as an extroverted CEO is more likely to create a team culture, which confirms hypothesis 1.a., a conscientious $\mathrm{CEO}$ tends to create a firm with a rational culture, which confirms hypothesis 1.c., and a CEO with a high openness to experience score tends to create an entrepreneurial culture, thus confirming hypothesis 1.e.. In addition, in inhibiting the creation of organizational silos and thus creating and developing internal informal cooperation networks among the firm's departments, as two (conscientiousness and openness to experience) of these three $\mathrm{CEO}$ psychological characteristics influence sharing, an extroverted $\mathrm{CEO}$ also impacts the organization's ability to create and develop informal networks, reflected in the way employees relate to each other to accomplish their work, regardless of any departmental or firm boundaries that might exist, or how the firm is viewed within the industry (communications and relationships). Finally, a CEO who is more open to experience or extroverted is more likely to encourage people to circulate between different departments, to assume different functions within the firm, and to work with whoever is necessary to get the work done, thus overcoming any working barriers (lack of a silo mentality). So, hypothesis 2.a., which predicts that CEOs with a high extraversion score are more likely to avoid organizational silos, and hypothesis 2.c., which predicts that CEOs with a high conscientiousness score are more likely to avoid organizational silos, were both confirmed.

Although no evidence could be found in the literature that a $\mathrm{CEO}$ with a high openness to experience score tends to avoid organizational silos, this research revealed that this occurs in the sectors studied.

However, regarding the third group of hypotheses, it was only possible to find evidence that age and

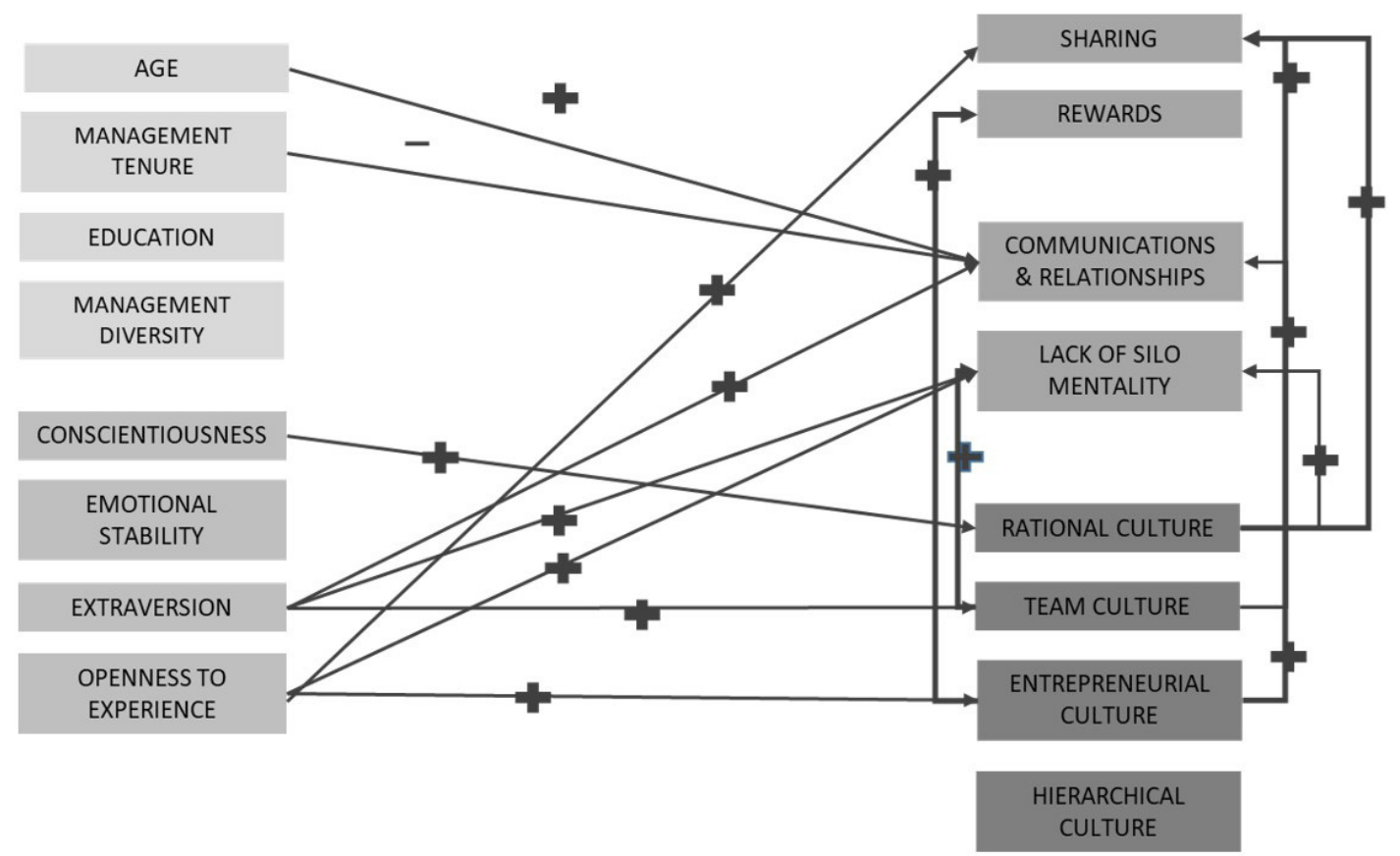

Source: SmartPLS

Figure 3. Theoretical framework with the statistically significant relationships 
management tenure have an impact on the organization's ability to create and develop internal informal cooperation networks, but not on organizational culture. So, it was not possible to confirm that younger CEOs or those with a high educational level tend to create entrepreneurial cultures, at least not in the sectors studied.

Furthermore, it should be mentioned that the other two observable CEO variables, education and management diversity, were left out of the model. In the two sectors studied, no evidence could be found of any influence of these variables on either organizational culture or organizational silos.

\section{Conclusions}

This research enriches the general understanding of how CEO characteristics influence organizations and their ability to establish internal cooperation networks, by discussing how different CEO observable variables (age, formal education, management experience, and management tenure) and psychological variables, assessed using the Big Five Framework, impact organizational culture and silos.

The general hypotheses of this study that CEO characteristics impact organizational culture and the creation of internal cooperation networks were generally supported by the empirical research. Clearly, there is a strong influence of CEO psychological variables such as conscientiousness, extraversion, and openness to experience on both organizational culture and the ability to create and develop informal networks. Although no evidence could be found of any influence of observable $\mathrm{CEO}$ variables on organizational culture in either the accommodation or food, beverage, and tobacco sectors, this research revealed that younger CEOs and CEOs with a shorter tenure in their jobs influence their organization's ability to create and develop informal networks, reflected in the way employees relate to each other to accomplish their work, regardless of any departmental or firm boundaries that might exist, or how the firm is viewed within the industry (communications and relationships).

Theoretically speaking, the main contribution of this research to the knowledge lies in the combination of different theoretical frameworks (Big Five Framework, Competing Values Framework, Upper Echelons Theory) and its empirical approach to testing the influence of CEO characteristics on organizational culture and on the ability of organizations to develop internal cooperation networks.
This research provided empirical support for the idea that personal traits impact organizational culture. The theory suggests that extroverted CEOs play a dominant role within the team (Gow et al., 2016), as they tend to be sociable, talkative, assertive, active, and full of energy (Costa \& McCrae, 1992), and so they are more likely to have a positive impact on organizational culture, mainly in terms of helping to create an organizational team culture. This was supported by the empirical research. So the idea that individuals with a high conscientiousness score tend to be more task-orientated and more likely to create rational cultures (O'Reilly III et al., 2014b) was confirmed.

In practical terms, this research can help managers to understand which CEO personality traits are best suited to organizational strategies that include the management of internal cooperation networks, a change of organizational culture, or a reduction in the silo effect within the organization.

Future research should also assess the impact of formal cooperation networks on firm performance, to help firms understand if the strategy of engaging in formal collaboration networks with other firms has any influence on firm performance. The possible moderating role of the observable variables in the relationship between CEO psychological characteristics and organizational culture and silos should also be investigated. The research should also be applied to other industries in order to find more evidence on the influence of observable $\mathrm{CEO}$ variables, namely age and management tenure, on the organization's ability to avoid silos, since this finding was not supported by the literature. It would also be interesting for future studies to provide further support for the conclusions of this research.

Hopefully, the results of this study will stimulate further research on CEO personality traits, observable variables, organizational culture, and cooperation networks.

\section{References}

Abatecola, G., Mandarelli, G., \& Poggesi, S. (2013). The personality factor: How top management teams make decisions. A literature review. Journal of Management \& Governance, 17(4), 1073-1100. https://doi.org/10.1007/ s10997-011-9189-y 
Alexander, E. (2014). How organizations act together: Interorganizational coordination in theory and practice. England: Routledge.

Anderson, J. C., \& Gerbing, D. W. (1988). Structural equation modeling in practice: A review and recommended two-step approach. Psychological bulletin, 103(3), 411-423. https://doi.org/10.1037/0033-2909.103.3.411

Araujo-Cabrera, Y., Suarez-Acosta, M. A., \& AguiarQuintana, T. (2017). Exploring the influence of CEO extraversion and openness to experience on firm performance: The mediating role of top management team behavioral integration. Journal of Leadership \& Organizational Studies, 24(2), 201-215. https://doi. org/10.1177/1548051816655991

Barrick, M. R., \& Mount, M. K. (1991). The big five personality dimensions and job performance: A metaanalysis. Personnel Psychology, 44(1), 1-26. https://doi. org/10.1111/j.1744-6570.1991.tb00688.x

Barsade, S. G., Ward, A. J., Turner, J. D. F., \& Sonnenfeld, J. A. (2000). To your heart's content: A model of affective diversity in top management teams. Administrative Science Quarterly, 45(4), 802-836. https://doi.org/10.2307/2667020

Blundell, R., Dearden, L., Meghir, C., \& Sianesi, B. (1999). Human capital investment: The returns from education and training to the individual, the firm and the economy. Fiscal studies, 20(1), 1-23. https://doi. org/10.1111/j.1475-5890.1999.tb00001.x

Buschgens, T., Bausch, A., \& Balkin, D. B. (2013). Organizational culture and innovation: A meta-analytic review. Journal of Product Innovation Management, 30(4), 763-781. https://doi.org/10.1111/jpim.12021

Cameron, K. (2009). An introduction to the competing values framework. Organizational culture white paper. Haworth. Retrieved from https://www.thercfgroup.com/ files/resources/an_introduction_to_the_competing values_framework.pdf

Carpenter, M. A., Geletkanycz, M. A., \& Sanders, W. G. (2004). Upper echelons research revisited: Antecedents, elements, and consequences of top management team composition. Journal of Management, 30(6), 749-778. https://doi.org/10.1016/j.jm.2004.06.001
Chin, W. W. (1998). The partial least squares approach for structural equation modeling. In G. A. Marcoulides (Ed.), Methodology for business and management. Modern methods for business research (p. 295-336). Lawrence Erlbaum Associates Publishers.

Cilliers, F., \& Greyvenstein, H. (2012). The impact of silo mentality on team identity: An organisational case study. Journal of Industrial Psychology, 38(2), 1-9. DOI: 10.4102/sajip.v38i2.993

Costa, P. T., Jr., \& McCrae, R. R. (1992). Four ways five factors are basic. Personality and Individual Differences, 13(6), 653-665. https://doi.org/10.1016/0191-8869(92)90236-I

Cromity, J., \& Stricker, U. (2011). Silo persistence: It's on the technology, it's the culture. New Review of Information Networking, 16(2), 167-184. https://doi.org/10.1080/1 3614576.2011.619924

Crossland, C., \& Hambrick, D. C. (2007). How national systems differ in their constraints on corporate executives: a study of CEO effects in three countries. Strategic Management Journal, 28(8), 767-789. DOI: 10.1002/smj.610

Digman, J. M. (1990). Personality structure: Emergence of the five-factor model. Annual Review of Psychology, 41, 417440. https://doi.org/10.1146/annurev.ps.41.020190.002221

Eisenhardt, K. M., \& Schoonhoven, C. B. (1996). Resourcebased view of strategic alliance formation: Strategic and social effects in entrepreneurial firms. Organization Science, 7, 136-150. https://doi.org/10.1287/orsc.7.2.136

Fenwick, T., Seville, E., \& Brunsdon, D. (2009). Reducing the impact of organisational silos on resilience: A report on the impact of silos on resilience and how the impacts might be reduced. New Zealand: Resilient Organisations Research Programme. Retrieved from http://hdl.handle. net/10092/9468

Finkelstein, S., \& Hambrick, D. C. (1990). Top management team tenure and organizational outcomes: The moderating role of managerial discretion. Administrative Science Quarterly, 35, 484-503. https://doi.org/10.2307/2393314

Finkelstein, S., Hambrick, D. C., \& Cannella, A. A. (2009). Strategic leadership: Theory and research on executives, 
top management teams, and boards. New York: Oxford University Press.

Giberson, T. R., Resick, C. J., Dickson, M. W., Mitchelson, J. K., Randall, K. R., \& Clark, M. A. (2009). Leadership and organizational culture: Linking CEO characteristics to cultural values. Journal of Business and Psychology, 24(2), 123-137. https://doi.org/10.1007/s10869-009-9109-1

Goh, S. (2002). Managing effective knowledge transfer: An integrative framework and some practice implications. Journal of Knowledge Management, 6(1), 23-30. https:// doi.org/10.1108/13673270210417664

Gow, I. D., Kaplan, S. N., Larcker, D. F., \& Zakolyukina, A. A. (2016). CEO Personality and Firm Policies. (NBER Working Paper Series, No. 22435). National Bureau of Economic Research: Cambridge. Retrieved from https:// www.nber.org/system/files/working_papers/w22435/ w22435.pdf

Grabowski, L., Neher, C., Crim, T., \& Mathiassen, L. (2015). Competing values framework application to organizational effectiveness in voluntary organizations: A case study. Nonprofit and Voluntary Sector Quarterly, 44(5), 908-923. doi:10.1177/0899764014546488

Granovetter, M. (1985). Economic action and social structure: The problem of embeddedness. American Journal of Sociology, 91(3), 481-510. Retrieved from https://www. jstor.org/stable/2780199

Groysberg, B., Lee, J., Price, J., \& Cheng, J. Y.-J. (2018). The leader's guide to corporate culture. Harvard Business Review, 96. Retrieved from https://hbr.org/2018/01/theleaders-guide-to-corporate-culture

Hair, J. F., Black, W. C., Babin, B. J., Anderson, R. E. (2010). Multivariate data analysis (7th ed.). New Jersey: Pearson.

Hambrick, D. C. (1982). Environmental scanning and organizational strategy. Strategic Management Journal, 3, 159-174. https://doi.org/10.1002/smj.4250030207

Hambrick, D. C., \& Mason, P. A. (1984). Upper echelons: The organization as a reflection of its top managers. Academy of Management Review, 9, 193-206. https://doi. org/10.5465/amr.1984.4277628
Hambrick, D. C. (2007). Upper echelons theory: An update. Academy of Management Review, 32(2), 334-343. https://doi.org/10.2307/20159303

Hambrick, D. C., \& Quigley, T. J. (2014). Toward more accurate contextualization of the CEO effect on firm performance. Strategic Management Journal, 35, 473-491. https://doi.org/10.1002/smj.2108

Helfrich, C. D., Li, Y., Mohr, D. C., Meterko, M., \& Sales, A. E. (2007). Assessing an organizational culture instrument based on the Competing Values framework: Exploratory and confirmatory factor analyses. Implementation Science, 2(13), 2-13. https://doi.org/10.1186/1748-5908-2-13

Hogan, S. J., \& Coote, L. V. (2014). Organizational culture, innovation, and performance: A test of Schein's model. Journal of Business Research, 67(8), 1609-1621. doi:10.1016/j.jbusres.2013.09.007

Hotaran, I. (2009). Silo effect versus supply chain effect. Review of International Comparative Management, 1 (Special Number), 216-221. http://www.rmci.ase.ro/ro/no10vol1S/ Vol10_SN_No1_Article32.pdf

Johanson, J., \& Vahlne, J.-E. (2009). The Uppsala internationalization process model revisited: From liability of foreignness to liability of outsidership. Journal of International Business Studies, 40(9), 1411-1431. doi:10.1057/jibs.2009.24

Kalliath, T. J., Bluedorn, A. C., \& Strube, M. J. (1999). A test of value congruence effects. Journal of Organizational Behavior, 20, 1175-1198.

Kaplan, S. N., \& Sorensen, M. (2017). Are CEOs different? Characteristics of top managers. (Working Paper, no. 23832), Cambridge: National Bureau of Economic Research. DOI 10.3386/w23832

Karami, A., Analoui, F., \& Korak Kakabadse, N. (2006). The CEOs' characteristics and their strategy development in the UK SME sector: An empirical study. Journal of Management Development, 25(4), 316-324.

Katz, D., \& Kahn, R. L. (1966). Social Psychology of Organizations. New York: Wiley.

Lee, A. V., Vargo, J., \& Seville, E. (2013). Developing a tool to measure and compare organizations' resilience. Natural hazards review, 14(1), 29-41. 
Luo, X., Kanuri, V. K., \& Andrews, M. (2014). How does $\mathrm{CEO}$ tenure matter? The mediating role of firm-employee and firm-customer relationships. Strategic Management Journal, 35(4), 492-511. doi:10.1002/smj.2112

Marôco, J. (2010). Análise de equaçôes estruturais: Fundamentos teóricos, software \& aplicaçôes. ReportNumber, Lda.

Maroco, J., \& Garcia-Marques, T. (2006). Qual a fiabilidade do alfa de Cronbach? Questóes antigas e soluçōes modernas? Laboratório de psicologia, 4(1), 65-90. Retrieved from http:// publicacoes.ispa.pt/index.php/lp/article/viewFile/763/706

Melé, D. (2003). Organizational humanizing cultures: Do they generate social capital? Journal of Business Ethics, 45, 3-14.

Nadkarni, S., \& Herrmann, P. O. L. (2010). CEO personality, strategic flexibility, and firm performance: The case of the Indian business process outsourcing industry. Academy of Management Journal, 53(5), 1050-1050-1073. doi:10.5465/AMJ.2010.54533196

O’Reilly III, C. A., Doerr, B., Caldwell, D. F., \& Chatman, J. A. (2014a). Narcissistic CEOs and executive compensation. The Leadership Quarterly, 25(2), 218-231.

O'Reilly III, C. A., Caldwell, D. F., Chatman, J. A., \& Doerr, B. (2014b). The promise and problems of organizational culture: $\mathrm{CEO}$ personality, culture, and firm performance. Group \& Organization Management, 39(6), 595-625.

Papadakis, V. M., \& Barwise, P. (2002). How much do CEOs and Top Managers matter in Strategic decisionmaking? British Journal of Management, 13, 83-95.

Peterson, R. S., Smith, D. B., \& Martorana, P. V. O., P. D. (2003). The impact of chief executive officer personality on top management team dynamics: One mechanism by which leadership affects organizational performance. Journal of Applied Psychology, 88, 795-808.

Quinn, R. E., \& Rohrbaugh. (1983). A spatial model of effectiveness criteria: Towards a competing values approach to organizational analysis. Management Science, 29(3), 363-377.

Schein, E. H. (1984). Coming to a new awareness of organizational culture. Sloan Management Review, 25(2), 1-16.
Schein, E. H. (1996). Culture: The missing concept in organization studies. Administrative Science Quarterly, 41, 229-240.

Schneider, B. (1987). The people make the place. Personnel Psychology, 40, 437-453.

Schütz, P., \& Bloch, B. (2006). The "silo-virus": Diagnosing and curing departmental groupthink. Team Performance Management, 12(1/2), 31-43.

Simons, T., Pelled, L. H., \& Smith, K. A. (1999). Making use of difference: Diversity, debate, and decision comprehensiveness in top management teams. Academy of Management Journal, 42(6), 662-673.

Stone, F. (2004a, Spring). Deconstructing Silos and Supporting Collaboration. Employment Relations Today, 31(1), 11-18. Doi: 10.1002/ert.20001

Stone, F. (2004b). Deconstructing silos and supporting collaboration. Employment Relations Today, 31(1), 11-18. doi:10.1002/ert.20001

Ullman, J. B., \& Bentler, P. M. (2012). Structural equation modeling. In I. B. Weiner, Handbook of Psychology (2nd ed.), Cap. 23 - pp. 661-690. https://doi. org/10.1002/9781118133880.hop202023

Vatanpour, H., Khorramnia, A., \& Forutan, N. (2013). Silo Effect a Prominence Factor to Decrease Efficiency of Pharmaceutical Industry. Iranian Journal of Pharmaceutical Research, Winter (12), 207-216.

Wang, G., Holmes, R. M., Oh, I.-S., \& Zhu, W. (2016a). Do CEOs matter to firm strategic actions and firm performance? A meta-analytic investigation based on upper echelons theory. Personnel Psychology, 69(4), 775862. doi:10.1111/peps. 12140

Wong, K. K.-K. (2013). Partial least squares structural equation modeling (PLS-SEM) techniques using SmartPLS. Marketing Bulletin, 24(1), 1-32.

Zacharias, N. A., Six, B., Schiereck, D., \& Stock, R. M. (2015). CEO influences on firms' strategic actions: A comparison of CEO-, firm-, and industry-level effects. Journal of Business Research, 68(11), 2338-2338-2346. doi:10.1016/j.jbusres.2015.03.045 


\section{Appendix I}

\section{Scales Used to Measure the Different Constructs}

\section{- Big Five Framework}

\begin{tabular}{|c|c|c|c|}
\hline \multirow[t]{15}{*}{ Big 5 Factor } & A15.1 & $\begin{array}{l}\text { Is original, comes up with new } \\
\text { ideas. }\end{array}$ & Openness to Experience \\
\hline & A15.2 & Values artistic experiences. & \\
\hline & A15.3 & Has an active imagination. & \\
\hline & A15.4 & Does a thorough job. & Conscientiousness \\
\hline & A15.5 & $\begin{array}{l}\text { Does things effectively and } \\
\text { efficiently. }\end{array}$ & \\
\hline & A15.6 & Tends to be lazy. & \\
\hline & A15.7 & Is communicative, talkative. & Extraversion \\
\hline & A15.8 & Is outgoing, sociable. & \\
\hline & A15.9 & Is reserved. & \\
\hline & A15.10 & Has a forgiving nature. & Agreeableness \\
\hline & A15.11 & $\begin{array}{l}\text { Is considerate and kind to } \\
\text { others. }\end{array}$ & \\
\hline & A15.12 & $\begin{array}{c}\text { Is sometimes somewhat rude to } \\
\text { others. }\end{array}$ & \\
\hline & A15.13 & Worries a lot. & Emotional Stability \\
\hline & A15.14 & Gets nervous easily. & \\
\hline & A15.15 & Is relaxed, handles stress well. & \\
\hline
\end{tabular}

A2.

A3.

A4.

A5.

A6.

A7.

A8.

A9.

A10.

A11.

A12.

A13.

A14.

\section{Age \\ Sex}

Highest completed degree

Field of Education and Training

Number of Years working in this firm

Number of Years of professional experience in this industry

In which industry was your previous professional experience?

Number of years you have been occupying the current position in this firm?

The functional area, in which you have acquired more experience before becoming CEO / General Manager / Director / Managing Partner / Manager ... company.

Were you one of the founder members?

Indicate the degree of dispersion of the company's capital:

Do you have any participation in the firm social capital?

How big is your share in the firm Social capital? 
- Competing Values Framework

$\begin{array}{ccc}\begin{array}{c}\text { Competing Values } \\ \text { Framework }\end{array} & \text { B9.1 } & \begin{array}{l}\text { My facility is a very dynamic and entrepreneurial place. } \\ \text { People are willing to stick their necks out and take risks. }\end{array}\end{array}$

B9.2 My facility is a very formalized and structured place.

Bureaucratic procedures generally govern what people do.

B9.3 Managers in my facility are warm and caring. They seek to

develop employees' full potential and act as their mentors or guides.

B9.4 Managers in my facility are risk-takers. They encourage employees to take risks and be innovative.

B9.5 Managers in my facility are rule-enforcers. They expect employees to follow established rules, policies, and procedures.

B9.6 Managers in my facility are coordinators and coaches. They help employees meet the facility's goals and objectives.

B9.7 The glue that holds my facility together is loyalty and tradition. Commitment to this facility runs high.

B9.8 The glue that holds my facility together is commitment to innovation and development. There is an emphasis on being first.

B9.9 The glue that holds my facility together is formal rules and policies. People feel that following the rules is important.

B9.10 The glue that holds my facility together is the emphasis on tasks and goal accomplishment. A production orientation is commonly shared.

B9.11 My facility emphasizes human resources. High cohesion and morale in the organization are important.

B9.12 My facility emphasizes growth and acquiring new resources. Readiness to meet new challenges is important.

B9.13 My facility emphasizes permanence and stability. Keeping things the same is important.

B9.14 My facility emphasizes competitive actions and achievement. Measurable goals are important.
Entrepreneurial

Hierarchical

Team

Entrepreneurial

Hierarchical

Rational

Team

Entrepreneurial

Hierarchical

Rational

Team

Entrepreneurial

Hierarchical

Rational

\section{- Silo Effect}

\begin{tabular}{|c|c|c|c|}
\hline Silo effect & $\begin{array}{c}\text { B10.2 } \\
\text { B10.3 } \\
\text { B10.4 } \\
\text { B10.5 } \\
\text { B10.6 } \\
\text { B10.7 } \\
\text { B10.8 } \\
\text { B10.9 } \\
\text { B10.10 }\end{array}$ & $\begin{array}{c}\text { There are measures that encourage the sharing of } \\
\text { information between departments. } \\
\text { Each department works autonomously. } \\
\text { Departments are interdependent. } \\
\text { Often there are joint activities after work. } \\
\text { Tasks are adequately defined and attributed. } \\
\text { Responsibilities are well defined. } \\
\text { Each department has its own culture. } \\
\text { There are financial rewards by departmental results. } \\
\text { There are financial rewards by organizational results. } \\
\text { People are encouraged to move between different } \\
\text { departments or try different roles within our } \\
\text { organization } \\
\text { to gain experience. } \\
\text { in our organization. } \\
\text { There is an excellent sense of teamwork and camaraderie } \\
\text { In our organization, it is important that there are no } \\
\text { barriers which stop us from working well with each } \\
\text { other. } \\
\text { In our organization, it is important that there are no } \\
\text { barriers } \\
\text { which stop us from working well with other } \\
\text { organizations. } \\
\text { Our organization is regarded as an active participant in } \\
\text { industry and sector groups. } \\
\text { People in our organization work with who ever they } \\
\text { need to } \\
\text { work with to get the job done well, regardless of } \\
\text { departmental or organizational boundaries. } \\
\text { If our organization was unable to operate for } 3 \text { months, } \\
\text { the } \\
\text { relationship we have with our suppliers and customers } \\
\text { would help us to recover rapidly. }\end{array}$ & $\begin{array}{c}\text { Silos (Own elaboration based } \\
\text { on existing literature (Cilliers \& } \\
\text { Greyvenstein, 2012; Stone, 2004a) }\end{array}$ \\
\hline
\end{tabular}




\section{Supporting Agencies:}

No supporting agencies to declare.

\section{Conflicts of interest:}

The authors have no conflict of interest to declare.

\section{Copyrights:}

RBGN owns the copyrights of this published content.

\section{Plagiarism analysis:}

RBGN performs plagiarism analysis on all its articles at the time of submission and after approval of the manuscript using the iThenticate tool.

\section{Authors:}

1. Cristina, Mouta, Polytechnic of Porto, Vila do Conde, Portugal.

E-mail: Cristina.mouta@gmail.com

2. Raquel, Meneses, University of Porto, Porto, Portugal.

E-mail: raquelm@fep.up.pt

\section{Authors' Contributions:}

Cristina, Mouta: Definition of research problem; Development of hypotheses or research questions (empirical studies); Development of theoretical propositions (theoretical work); Definition of methodological procedures; Data Collection; Literature review; Statistical analysis; Analysis and interpretation of data; Critical revision of the manuscript; Manuscript writing.

Raquel, Meneses: Definition of research problem; Development of hypotheses or research questions (empirical studies); Definition of methodological procedures; Literature review; Statistical analysis; Analysis and interpretation of data; Critical revision of the manuscript. 